\title{
SUBGRADE IMPROVEMENT USING NO FINES CONCRETE NAILS
}

\author{
J.Ranjitha ${ }^{1}$, M.R.Rajasekhara ${ }^{2}$ \\ ${ }^{I}$ Assistant Professor, Department of Civil Engineering, Dayananda Sagar College of Engineering, VTU, Karnataka, \\ India \\ ${ }^{2}$ Professor, Department of Civil Engineering, Dayananda Sagar College of Engineering, VTU, Karnataka, India
}

\begin{abstract}
Black Cotton Soil is very weak in nature and is not preferred as subgrade soil. It has to be stabilized to be used in the the pavement as subgrade material. Many stabilizers and techniques are available in the market as a solution to this problem. The present study, however, is aimed at using alternate and comparatively low cost technique to stabilize the Black Cotton Soil. The soil nailing concept used for reinforcing embankments and is considered and applied accordingly to the subgrade with certain changes in specification. This can enhance the strength of Black Cotton subgrade soil and minimize settlement.

The conventional methods of ground improvement technique have proven costlier. In the present study an attempt is made to use the concept of ground improvement technique for stabilizing the black cotton soil Subgrade by driving nails. No fines concrete tapered nails in the form of concrete nails are driven into the subgrade soil at an inclination of $90^{\circ}$. These nails are preferred as they are corrosion resistant in comparison with reinforced steel. The diameter and height is varied to get concrete nails of three different dimensions. California Bearing ratio test value is analyzed.
\end{abstract}

No fines concrete can be effectively used to improve the stability of the weak subgrade than the conventional concrete and is more economical. The method can be adopted effectively for village roads carrying low traffic

Keywords: Weak soil, Subgrade, no fines concrete nail, California bearing ratio(CBR)

\section{INTRODUCTION}

A subgrade can be defined as a native soil compacted to withstand the loads above it. It is an integral part of the road pavement structure as it provides the support to the pavement from beneath. It is a layer required in many structures such as pavements, although it needs to have certain characteristics.

The subgrade soil and its properties are important in the design of pavement structure. The main function of the subgrade is to provide sufficient stability under adverse climatic and loading conditions. The soil subgrade is a layer of natural soil prepared to receive the load of the layers of pavement materials placed over it. The loads on the pavement are ultimately received by the soil subgrade for dispersion to the earth mass. It means the pressure transmitted on to the top of the subgrade is within the allowable limit. It is essential that at no time, the soil subgrade is over stressed. The weak subgrade whether in cut or fill should be well compacted to utilize its full strength to economize the overall thickness of the pavement required. But in case this supporting layer does not come upto the expectations, the same is treated or stabilized to suit the requirements.

\subsection{Weak Soil -Black Cotton soil}

Black cotton soil is a weak soil for engineering construction. The colour of this soil is reddish brown to black and this helps for cultivation of cotton. They are found in extensive regions of the Deccan Trap. They cover almost $20 \%$ of the land mass in India. Black cotton soil has low bearing capacity and high swelling and shrinkage characteristics leading to noticeable changes in volume and strength due to change in moisture content. The change in volume causes continuous damage to the pavement structure.

Black cotton soil is considered as one of the most weak soils of all types. The major drawback of using black cotton soil as a construction material is that it expands when it comes in contact with moisture content and expands to an amount of 20 to $30 \%$ by the volume. Hence it is called as the expansive soil. When the wet soil is exposed to heat or sunlight it get shrinks and the cracks develops which is never encouraging factor for a construction material. The weak subgrade whether in cut or fill shall be stabilized to utilize its full strength and thereby economize the overall thickness of the pavement required.

\subsection{No Fines Concrete Nail}

No-fines concrete as the term implies, is a kind of concrete from which the fine aggregate fraction has been omitted. This concrete is made up of only coarse aggregate, cement and water. Very often only single sized coarse aggregate, of size passing through $20 \mathrm{~mm}$ retained on $10 \mathrm{~mm}$ is used.

The advantages of no fines concrete include - the density of no fines concrete is very low. No fines concrete does not 
segregate and the capillary movement of water is almost nil. It has better thermal insulating characters due to the presence of large voids. This concrete can be used by dropping from a permissible height. Shrinkage is also lower than normal concrete. No fine concrete lightweight and the formwork can be removed earlier. No mechanical vibrator is required for compacting no fines concrete, simple roding method is sufficient for full compaction and It gives better and attractive appearances. Production cost is comparatively lower than other conventional concrete because lower cement content is used.

No fines concrete also has few disadvantages like, the strength of no-fines concrete is lower than ordinary concrete and no-fines concrete can not be used in reinforced concrete structure. The consistency of no-fines concrete can not be measured by any available standard methods such as slump test, compacting factor test etc.

\section{LITERATURE REVIEW}

Y M Chenga et al. ( 2) , used the concept of soil nailing is to increase the global shear strength of the soil by closely spaced nails Fracture grouting has been successfully adopted in settlement compensation. In this technique, the foundation is anchored at the bottom of the granular pile to a mild steel plate with the help of a mild steel rod embedded in the foundation. Enormous shear resistance will be mobilized along the pile-soil interface and resists the uplift. In this study the transverse pile spacing was varied and found that the group efficiency also was based on the location of the piles.

Based on the research on displacement grouting by Soga et $\left.\mathrm{al}^{(} 3\right)$ and $\mathrm{Au}^{(4)}$, subsurface cavity expansion in clay induced by fracture grouting is not only able to generate upward displacement of clay, but there is also an increase in the effective stress leading to consolidation which results in settlement compensation and shear strength enhancement in normally consolidated clay. As a result, fracture grouting can be a cost effective technique for ground improvement in soft ground condition. The Geo nail system is introduced and the verification of this system is accomplished through trial tests and in-situ tests.

Smethurst and Powerie( 5 ), Reinforced Concrete Piles were Used to Stabilize a Railway Embankment.Instrumented discrete reinforced concrete piles were used to stabilize a 26-ft high railway embankment of Weald Clay at Hildenborough, Kent, UK. Remediation of the embankment was carried out to solve long-term serviceability problems, including excessive side slope displacements and track settlements. Stability calculations carried out after an initial site investigation showed the north slopes of the embankment to be close to failure. .

According to Dipty sarin, Girish M S( 6 ) , the degree of improvement of a soft soil can be brought about by stone columns due to two factors. The first one is inclusion of a stiffer column material (such as crushed stones, gravel, etc.) in the soft soil. The second factor is the densification of the surrounding soft soil during the installation. The most significant factors appear to include pile potting, Undrained shear strength of clay, Soil layer thickness and load surcharge intensity. He also indicated that delayed installation of pile had sunstantial benefit in reducing pile bending movements and lateral moments.

\section{OBJECTIVE OF THE STUDY}

- To study the properties of weak subgrade soil.

- Use of low cost material like no fines concrete cones to obtain better strength of the subgrade.

- Effect of size of no fines concrete nails on Subgrade strength of the soil.

- Feasibility study to overcome subgrade failure.

\section{METHODOLOGY}

For the present work the weak soil (Black Cotton soil) was procured from Raichur district, Karnataka. The soil was taken from a depth of 1.5 meter from the natural ground level. The obtained soil was dried and pulverised.

No fines concrete is a mixture of cement, water, and a single sized coarse aggregate combined to produce a porous structural material. It is referred by different names including zero-fines concrete, pervious concrete and porous concrete. In this study 53 grade cement and coarse aggregate which is passing $20 \mathrm{~mm}$ and retained on $10 \mathrm{~mm}$ sieve is used. The details of no fines concrete nails used are as given in Table 1.

Table 1: Dimension of no fines concrete cones

\begin{tabular}{|l|l|l|l|}
\hline $\begin{array}{l}\text { Cone } \\
\text { No. }\end{array}$ & $\begin{array}{l}\text { Top Diameter, } \\
\mathrm{cm}\end{array}$ & $\begin{array}{l}\text { Bottom } \\
\text { Diameter, cm }\end{array}$ & Height, cm \\
\hline 1 & 5 & 2.5 & 2.16 \\
\hline 2 & 7.5 & 2.5 & 4.33 \\
\hline 3 & 10 & 2.5 & 6.49 \\
\hline
\end{tabular}

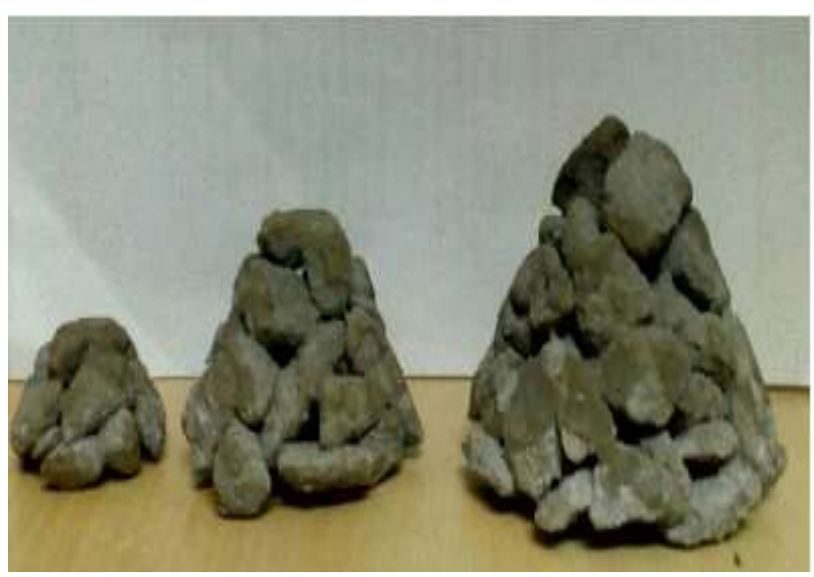

Fig 1: Casted no-fines concrete nails 
For CBR test, static compaction procedure is carried out.6kg of soil sample is thoroughly mixed at OMC The CBR mould is filled in 3 layers with each layer being tamped 56 times. The center portion of the soil filled in the mould is excavated to the size of the no fines concrete nail and it is then inserted. This procedure is repeated for each size of the nail.

\section{EXPERIMENTAL STUDY}

The laboratory studies conducted to study the basic properties of the soil is as given in Table 2 .

Table 2: Properties of weak soil used in the study

\begin{tabular}{|l|l|l|}
\hline Sl.No & Experiments & Result \\
\hline 1 & Specific Gravity & 2.35 \\
\hline 2 & Liquid Limit & $54.20 \%$ \\
\hline 3 & Plastic Limit & $29 \%$ \\
\hline 4 & Shrinkage Limit & $12.80 \%$ \\
\hline 5 & $\begin{array}{l}\text { Optimum Moisture } \\
\text { Content }\end{array}$ & $26.86 \%$ \\
\hline 6 & Maximum Dry Density & $1.470 \mathrm{~g} / \mathrm{cc}$ \\
\hline \multirow{2}{*}{7} & & $\begin{array}{l}\text { Soaked condition } \\
1.56 \%\end{array}$ \\
\cline { 3 - 4 } & California Bearing Ratio & $\begin{array}{l}\text { Unsoaked condition } \\
3.12 \%\end{array}$ \\
\hline
\end{tabular}

The CBR values of soil driven with three different nails are determined as per IS code. Fig. 2 to Fig.5 represents the load versus penetration values of CBR test for both soaked and unsoaked conditions.

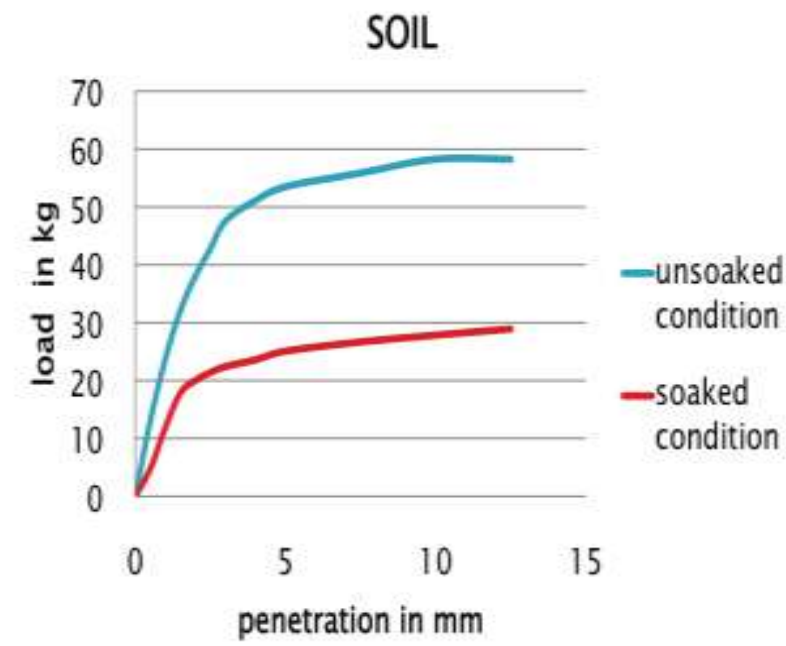

Fig 2: Load-penetration values of weak soil at $2.5 \mathrm{~mm}$ penetration level CBR test

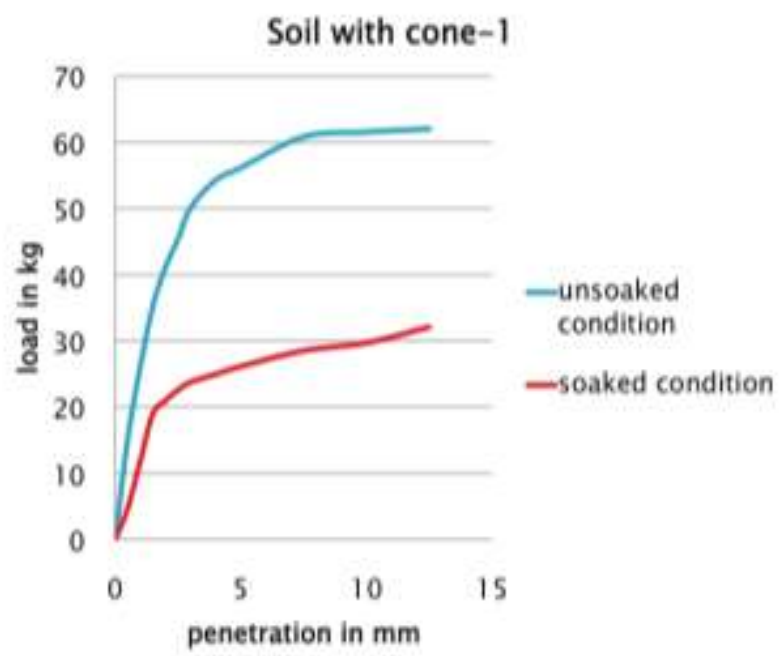

Fig 3: Load-penetration values of soil treated with cone-1 at $2.5 \mathrm{~mm}$ penetration level CBR test

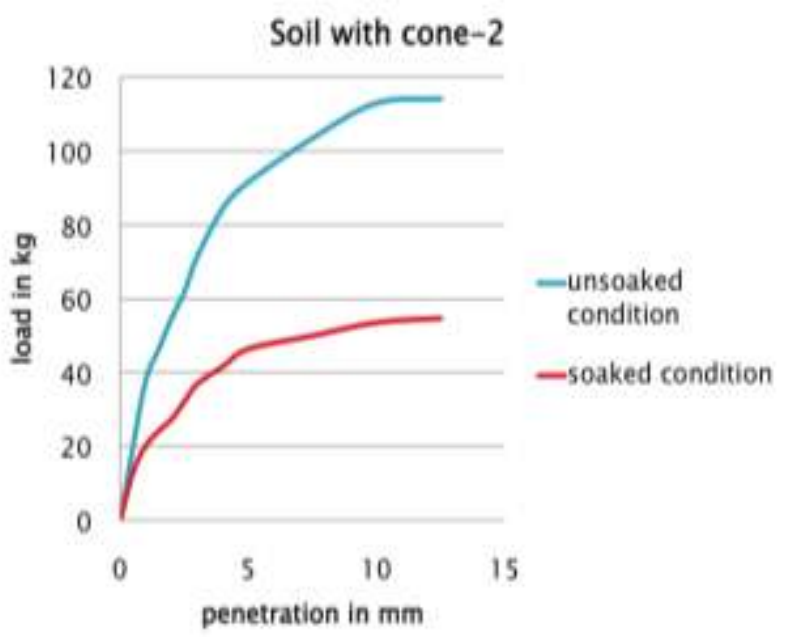

Fig 4: Load-penetration values of soil treated with cone-2 at $2.5 \mathrm{~mm}$ penetration level CBR test



Fig 5: Load-penetration values of soil treated with cone-3 at $2.5 \mathrm{~mm}$ penetration level CBR test 
From the load-penetration curves, CBR value of weak soil as well as the treated soil is determined and compared. Table. 3 and Table. 4 gives the CBR values of untreated and treated soil for unsoaked and soaked conditions respectively.

Table 3: CBR values for unsoaked conditions of soil

\begin{tabular}{|l|l|l|}
\hline Soil condition & $\begin{array}{l}\text { CBR value at } \\
2.5 \mathrm{~mm}\end{array}$ & $\begin{array}{l}\text { CBR value at } \\
5 \mathrm{~mm}\end{array}$ \\
\hline Weak soil & 3.12 & 2.6 \\
\hline Soil with cone-1 & 3.31 & 2.73 \\
\hline Soil with cone-2 & 4.51 & 4.46 \\
\hline Soil with cone-3 & 7.98 & 6.81 \\
\hline
\end{tabular}

Table 4: CBR values for soaked conditions of soil

\begin{tabular}{|l|l|l|}
\hline Soil conditions & $\begin{array}{l}\text { CBR value for } \\
2.5 \mathrm{~mm}\end{array}$ & $\begin{array}{l}\text { CBR values for } \\
5 \mathrm{~mm}\end{array}$ \\
\hline Weak soil & 1.56 & 1.16 \\
\hline Soil with cone-1 & 1.64 & 1.27 \\
\hline Soil with cone-2 & 2.34 & 2.26 \\
\hline Soil with cone-3 & 3.91 & 3.47 \\
\hline
\end{tabular}

CBR values at $2.5 \mathrm{~mm}$ penetration is found more than that at $5 \mathrm{~mm}$ penetration. The increase in CBR value at $2.5 \mathrm{~mm}$ penetration for untreated and treated soil is compared separately for unsoaked and soaked conditions. This is represented in Fig.6 and Fig.7.

\section{UNSOAKED CONDITION}

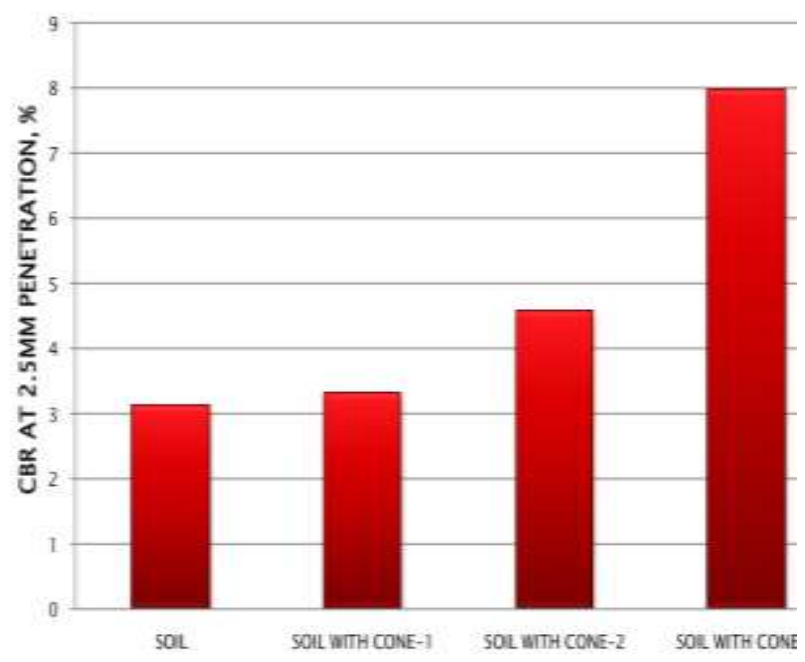

Fig 6: Improvement in CBR values under unsoaked conditions of soil

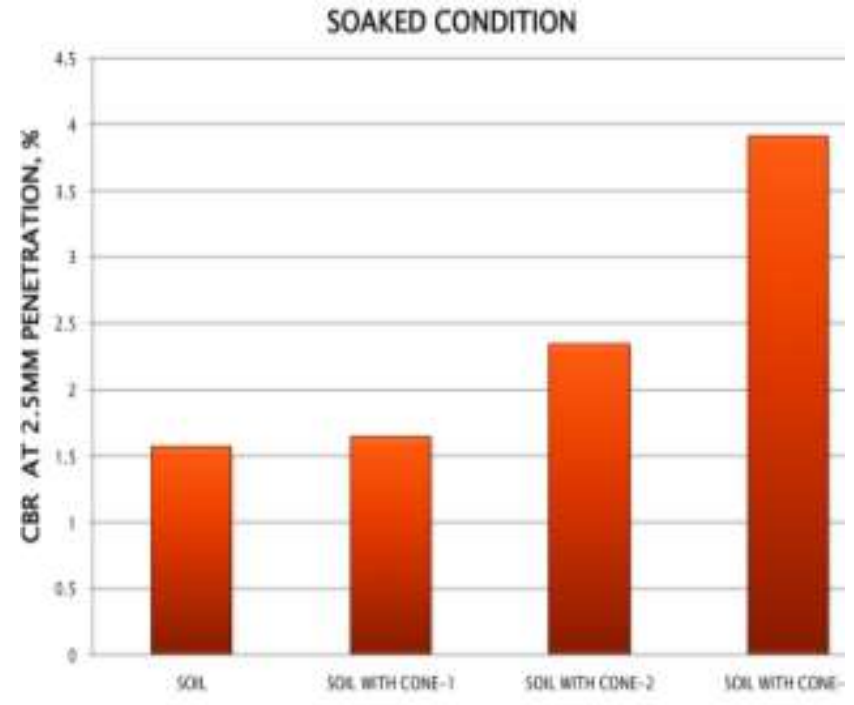

Fig 7: Improvement in CBR values under soaked conditions of soil

\section{CONCLUSION}

- Driving of no fines concrete nails into soil improves the CBR values and also the load carrying capacity of black cotton subgrade soil can be enhanced.

- $\mathrm{CBR}$ value increases with the insertion of no fines concrete nail.

- Based on the results it can be concluded that nailing technique adapted can be used more effectively for Black cotton soil stabilization.

- No fines concrete which has comparatively less strength than normal concrete is effective for improving load settlement characteristics of Black cotton soil when used as nails.

\section{REFERENCES}

[1]. Bhyravavajhala(2003).,'Experimental and theoretical study of pile- anchors on weak soil'ICGGE-2004 IIT Bombay.

[2]. Y M Chenga(2012),"Improvement of global shear strength of soil using nailing techniques", Journal of Geotechnical and Geo-Environmental Engineering pp802811

[3]. Soga(2001)," A study on displacement grouting and subsurface cavity expansion in clay" EJGE, Vol14,pp2-12.

[4]. Au and Yung Ranjkish, "Geo nail system for ground improvement in soft soil", Geolith Consultants Inc.

[5]. Smethurst and Powerie(2007), "Stabilization of railway embankment using reinforced concrete piles". The fourth International Geo Technical engineering Conference -Cairo University, pp 415-426.

[6]. Dipty Sarin, Girish M S(2009) "Inclusion of a stiffer column material in the soft soil ". Design and construction of deep foundation, Vol. 3 pp 1403-1412.

[7]. IS:2720(PART-4)-1985 Method of test for soil(Grain size analysis), BIS, New Delhi

[8]. IS:2720(PART-6)-1972 Method of tests for soil(Determination of shrinkage factors). BIS, New Delhi 
[9]. IS:2720(part-7)-1980 Method of test for soil(Determination of water content) BIS, New Delhi [10]. IS:2720-1991 [11]. IS:10262-2009 Concrete mix proportioning, BIS, New Delhi.

[11]. IS:456-2000 Plain and reinforced concrete, BIS, New Delhi.

[12]. IS:383-1970 Specification for coarse and fine aggregate from natural sources for concrete, BIS, New Delhi.

\section{BIOGRAPHIES}

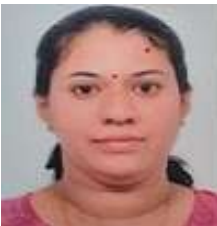

The author is an academician and pursuing Ph.D in the field of pavement engineering. Her areas of interest include pavement materials and construction and transportation engineering.

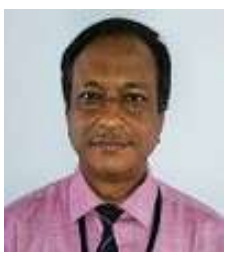

The author has worked under various capacities including being Head of the Department of Civil Engineering and Post Graduate Studies Coordinator. His areas of interest include pavement materials, traffic engineering and transport planning. 